\title{
Ancyrocephalidae (Monogenea) of Lake Tanganyika: Does the Cichlidogyrus parasite fauna of Interochromis loocki (Teleostei, Cichlidae) reflect its host's phylogenetic affinities?
}

\author{
Antoine Pariselle ${ }^{1,2}$, Maarten Van Steenberge ${ }^{3,4}$, Jos Snoeks ${ }^{3,4}$, Filip A.M. Volckaert ${ }^{3}$, Tine Huyse S $^{3,4}$, Maarten P.M. \\ Vanhove 3, $, 5,6,7^{-1}$ \\ ${ }^{1}$ Institut des Sciences de l'Évolution, IRD-CNRS-Université Montpellier 2, CC 063, Place Eugène Bataillon, 34095 \\ Montpellier cedex 05, France \\ ${ }^{2}$ Present address: Institut de Recherche pour le Développement, ISE-M, B.P. 1857, Yaoundé, Cameroon \\ ${ }^{3}$ Biology Department, Royal Museum for Central Africa, Leuvensesteenweg 13, B-3080 Tervuren, Belgium \\ ${ }^{4}$ Laboratory of Biodiversity and Evolutionary Genomics, Department of Biology, University of Leuven, Charles \\ Debériotstraat 32, B-3000 Leuven, Belgium \\ ${ }^{5}$ Department of Botany and Zoology, Faculty of Science, Masaryk University, Kotlářská 2, CZ-611 37 Brno, Czech \\ Republic \\ ${ }^{6}$ Institute of Marine Biological Resources and Inland Waters, Hellenic Centre for Marine Research, $46.7 \mathrm{~km}$ Athens- \\ Sounio Avenue, PO Box 712, Anavyssos GR-190 13, Greece \\ ${ }^{7}$ E-mail: maarten.vanhove@bio.kuleuven.be
}

Key words: Africa, Dactylogyridea, Petrochromis, Platyhelminthes, species description, Tropheini

\begin{abstract}
The faunal diversity of Lake Tanganyika, with its fish species flocks and its importance as a cradle and reservoir of ancient fish lineages seeding other radiations, has generated a considerable scientific interest in the fields of evolution and biodiversity. The Tropheini, an endemic Tanganyikan cichlid tribe, fills a peculiar phylogenetic position, being closely related to the haplochromine radiations of Lakes Malawi and Victoria. Several problems remain regarding their genus-level classification. For example, the monotypic genus Interochromis is phylogenetically nested within Petrochromis; its only representative, $I$. loocki, has often been reclassified. As monogenean flatworms are useful markers for fish phylogeny and taxonomy, the monogenean fauna of Interochromis loocki was examined and compared to that of other tropheine cichlids. Three new monogenean species belonging to Cichlidogyrus are described from Interochromis loocki: Cichlidogyrus buescheri Pariselle and Vanhove, sp. nov., Cichlidogyrus schreyenbrichardorum Pariselle and Vanhove, sp. nov. and Cichlidogyrus vealli Pariselle and Vanhove, sp. nov. Their haptoral anchors remind more of congeners infecting species of Petrochromis than of all Cichlidogyrus spp. hitherto described from other tropheine cichlids. Attachment organ morphology has been proven to mirror the phylogenetic affinities of Cichlidogyrus lineages. Therefore the monogenean parasite fauna of I. loocki reflects this host's position within Petrochromis. Moreover, I. loocki differs in habitat choice from Petrochromis spp. This study hence confirms that host range and host-specificity in Cichlidogyrus spp. parasitizing tropheines is determined by the host's phylogenetic position, rather than by a shared ecological niche.
\end{abstract}

\section{Contents}

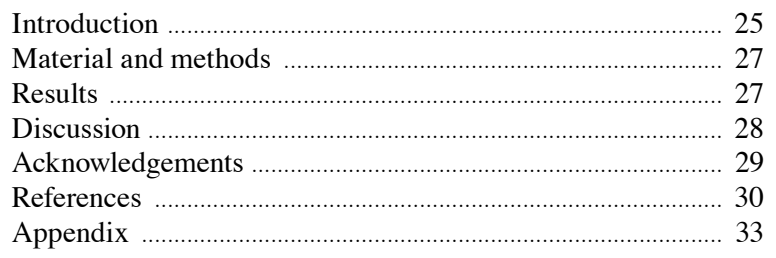

\section{Introduction}

Lake Tanganyika is, with an estimated age of 9-12 million years (Cohen et al., 1997), the oldest of the East African Great Lakes. Although less species-rich than Lakes Victoria and Malawi, its 250 endemic cichlids form the morphologically, behaviourally and phylogenetically most diverse lacustrine cichlid fauna (Snoeks, 2000) which acted as an evolutionary reservoir from which other lineages evolved (Salzburger et al., 2005). The lake's cichlids are grouped into 14 to 17 tribes (Poll, 1986; Takahashi, 2003; Koblmüller et al., 2008). One of these tribes, the Tropheini, is nested within the haplochromines, which contains the mega-diverse cichlid flocks of Lake Malawi and Lake Victoria (Salzburger et al., 2005). In comparison to these radiations, tropheines are relatively species-poor, as they currently only comprise 
24 species classified in nine genera (Poll, 1986; Takahashi, 2003; Takahashi and Koblmüller, 2014).

Traditionally, generic definitions of Lake Tanganyika cichlids are largely based on oral tooth morphology (Poll, 1986). For many tribes, this has proven to be an oversimplification (Sturmbauer et al., 2010). Yet, in tropheine cichlids, phylogenetic reconstructions to a large extent support the grouping of species based on similarities in oral morphology (Koblmüller et al. 2010; Van Steenberge, 2014). One tropheine species, Interochromis loocki (Poll, 1949), has, however, been particularly difficult to classify and its generic placement has changed frequently.

Interochromis loocki was described based on 13 specimens collected at Kigoma (Tanzania) (type locality) and Kalemie (Democratic Republic of Congo). Poll (1949) originally described the species as belonging to Limnotilapia Regan, 1920, which he considered to represent a 'limnetic' form of Tilapia Smith 1840. The species was later transferred to Simochromis Boulenger, 1898 when Greenwood (1978) synonymised Limnotilapia with Simochromis. This decision was motivated in a subsequent paper in which Greenwood (1979) stated that, although the type species of both genera, S. diagramma (Günther, 1894) and L. dardennii (Boulenger, 1899), differ greatly in osteological characters, I. loocki is intermediate between the two. Poll (1986) resurrected Limnotilapia; yet, as he did not refute Greenwood's (1979) observations, I. loocki remained in Simochromis. This was justified as Poll (1986) considered I. loocki closer to Simochromis than to Limnotilapia. Moreover, he claimed that the osteological similarities between both genera were also shared with other representatives of the Tropheini (Poll, 1986).

Interochromis Yamaoka, Hori and Kuwamura, 1998 was erected by Yamaoka et al. (1998) as a monotypic genus to harbour I. loocki. The reason for describing the genus was based on the morphological and ecological similarities between I. loocki and species of Petrochromis Boulenger, 1898 (Yamaoka et al., 1998) and the differences between I. loocki and species of Simochromis. Yamaoka et al. (1998) argued that, whereas members of Tropheus Boulenger, 1898, Simochromis, Pseudosimochromis Nelissen, 1977 and Limnotilapia are browsers that use their firmly set teeth to cut of strands of filamentous algae, Interochromis and Petrochromis spp. are grazers, or 'combers' (Yamaoka, 1997), which collect unicellular algae (mostly diatoms) using their loosely set teeth. Poll (1949) also mentioned the loosely fit teeth in his original description of I. loocki. However, he did not use it as a distinguishing character.
The main difference between Interochromis and Petrochromis is that the outer oral teeth of I. loocki are bicuspid, whereas species belonging to the latter genus have tricuspid outer teeth. The similarity in diet between I. loocki and Petrochromis spp. was also observed after stomach analyses (Muschick et al. 2012). Konings (1998) observed that juvenile I. loocki collect algae from plants, just as Petrochromis species collect these from rocks. Interochromis and Petrochromis were also shown to be closely related in a nuclear phylogeny of Tropheini (Koblmüller et al. 2010). Here, I. loocki rendered Petrochromis paraphyletic as it was sister to two Petrochromis species: P. orthognathus Matthes, 1959 and $P$. fasciolatus Boulenger, 1914. This is in agreement with Yamaoka (1997), who described the feeding behaviour of different Petrochromis species and who noticed the similarity between these two Petrochromis species and I. loocki.

In this study, we explore another perspective with regard to the question of the relationships of I. loocki. To this end, we investigate the monogenean gill parasite fauna infecting this species. Monogenean flatworms exhibit considerable potential for improving our understanding of their hosts' biogeography, phylogeny and taxonomy (Guégan and Lambert, 1990, Paugy et al., 1990; Pariselle, 1996; Boeger and Kritsky, 2003; Barson et al., 2010; Pariselle et al., 2011; Vanhove, 2012; Vanhove et al., 2013, 2014). Given their simple single-host lifecycle, high species diversity and relatively high hostspecificity, these flatworms are good markers for studying biodiversity and speciation in groups of closely related fishes (Pariselle et al., 2003b). The most species-rich genus on African cichlids is Cichlidogyrus Paperna, 1960 (Pariselle and Euzet, 2009). This genus is usually considered a member of the Ancyrocephalidae, although studies have suggested the group to be nonmonophyletic. In that case its representatives should be considered to belong to the Dactylogyridae (Kritsky and Boeger, 1989; Šimková et al., 2003, 2006; Plaisance et al., 2005). Cichlidogyrus spp. are common parasites of Tanganyikan cichlids (Vanhove et al., 2011a; Raeymaekers et al., 2013); thirteen new species have recently been described from Lake Tanganyika (Vanhove et al., 2011b; Gillardin et al., 2012; Muterezi Bukinga et al., 2012; Pariselle et al., 2014).

By characterising the morphological affinities of Cichlidogyrus species infecting I. loocki as a source of information on its phylogenetic position, we also aim to add to our understanding of what determines host range and host-specificity in the parasite fauna of littoral cichlids in Lake Tanganyika. In the phylogeny of 
the Tropheini, major clades are separated according to habitat preferences (Koblmüller et al., 2010). Therefore the evolution of tropheine cichlids can be explained by the general model of cichlid evolution as proposed by Danley and Kocher (2001). It describes how intra-lacustrine differentiation occurs at first by habitat segregation, then by specialisation to a certain trophic niche and finally by the emergence of differences in colour pattern. Although the original model (Danley and Kocher, 2001) describes a split between sand- and rock-dwelling lineages, a similar split between rock- and sediment-dwelling clades is observed in the phylogeny of the Tropheini (Koblmüller et al. 2010). However the phylogenetic position of I. loocki does not fit into this framework. Interochromis loocki occurs amongst macrophytes and in sediment-rich and muddy habitats (Yamaoka, 1997; Konings, 1998). Hence, it has the same habitat requirements as the 'sediment dwellers' (sensu Koblmüller et al., 2010), including representatives of the tropheine genera Simochromis, Limnotilapia, Pseudosimochromis and 'Ctenochromis' horei Günther, 1894 and 'Gnathochromis' pfefferi Boulenger, 1898. Nevertheless, I. loocki is nested within Petrochromis (Koblmüller et al., 2010). All representatives of Petrochromis feed on epilithic algae, which restricts them to Lake Tanganyika's rocky shores although P. orthognathus and P.fasciolatus have a larger tolerance to sediment (Konings, 1998). By comparing the Cichlidogyrus fauna infesting I. loocki with those of other Lake Tanganyika cichlids, we test whether the high host-specificity hitherto recorded in Cichlidogyrus spp. infecting littoral Tanganyikan cichlids, notably tropheines (Vanhove, 2012), is related to the habitat requirements of the host or to its phylogenetic affinities. In the first case, we expect I. loocki to harbour a parasite fauna similar to that of the sediment dwellers (Gillardin et al., 2012; Van Steenberge, 2014). In the latter scenario, we anticipate similarities between Cichlidogyrus spp. infecting I. loocki and those found on species of Petrochromis.

\section{Material and methods}

A specimen of Interochromis loocki (Fig. 1) was collected with a gill net off Kalambo Lodge ( $8^{\circ} 37^{\prime} 19^{\prime \prime}$ S; $31^{\circ} 12^{\prime} 00$ " E), along the Zambian shoreline of Lake Tanganyika (Fig. 2) in April 2008. It was fixed in pure ethanol and identified to the species level ex situ. Its gills were inspected for monogenean parasites using a stereomicroscope. Monogeneans were removed with a dissection needle. They were mounted on a slide under a cover-slip using ammonium picrate glycerine (Malmberg, 1957) or Hoyer's medium (see Humason, 1979). Monogeneans observed from I. loocki were compared with parasites reported from other Lake Tanganyikan hosts (Vanhove et al., 2011b; Gillardin et al., 2012; Muterezi Bukinga et al., 2012; Grégoir et al., 2014; Pariselle et al., 2014; Van Steenberge, 2014) and with specimens belonging to hitherto undescribed species, retrieved from tropheines (notably Petrochromis species) from the collections of the Royal Museum for Central Africa (RMCA).

Micrographs and measurements of the hardparts of haptor and male apparatus (MA) (also known as male copulatory organ) were taken based on Gussev (1962) using a Leica DM2500 microscope at a magnification of $\times 1000$ (oil immersion, $\times 10$ ocular) with the software LAS v.3.6 and a DFC 425 Leica camera. The numbering of the haptoral hardparts was adopted from ICOPA IV (Euzet and Prost, 1981); the terminology follows Pariselle and Euzet (1995) (i.e., 'uncinuli' for marginal hooks); and the metrics taken are shown in Fig. 3. Host taxon names and authorities follow Eschmeyer (2014).

\section{Results}

Three monogenean species were retrieved from the gills of Interochromis loocki, all belonging to Cichlidogyrus Paperna, 1960 sensu Paperna (1960) and Pariselle et al. (2003a). All three species are new to science; they are described in the Appendix, chiefly based on the morphology of the hardparts of the posterior attachment organ (haptor) and of the MA. Measurements on the newly described species are shown in Table 1. Type material was deposited in the invertebrate collection of the RMCA (Tervuren, Belgium), in the Muséum national d'Histoire naturelle (MNHN) (Paris, France) and in the Iziko South African Museum (SAMCTA) (Cape Town, Republic of South Africa). The symbiotype (Frey et al., 1992) was deposited in the RMCA.

The haptoral hardparts of the three Cichlidogyrus species found on I. loocki show considerable similarity with those of currently undescribed species of this genus infecting Petrochromis spp. (Fig. 4). This is particularly apparent in the point of the anchors, which is separated quite sharply from the rest of the anchor (whereas the blade is aligned less towards the guard in congeners from 'sediment dwellers': see Gillardin et al., 2012) and in the weak incision between the guard and shaft of the ventral anchor. 


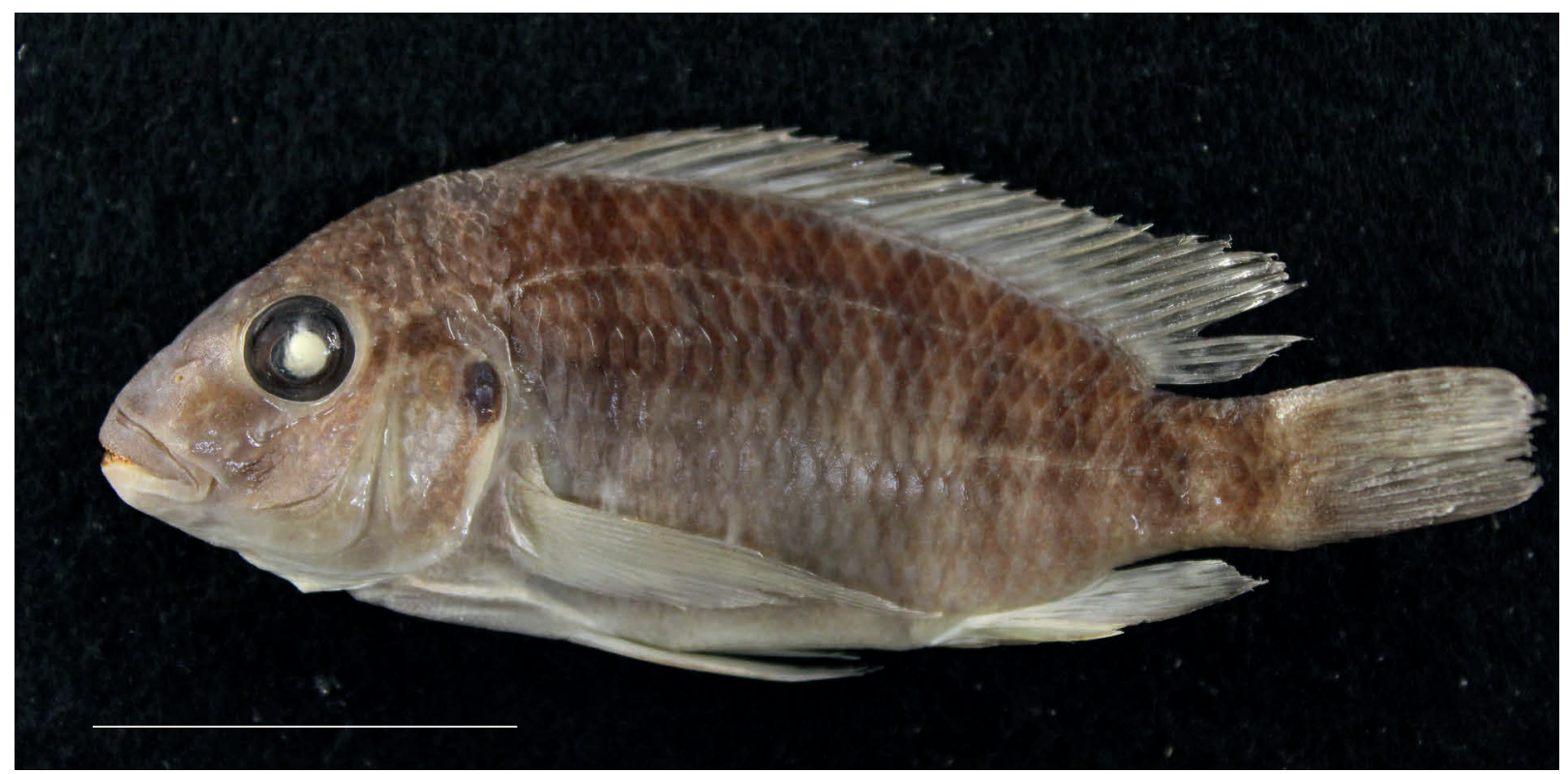

Fig. 1. The symbiotype (Interochromis loocki MRAC B3-36-P-1) of Cichlidogyrus buescheri sp. nov., C. schreyenbrichardorum sp. nov. and C. vealli sp. nov. from Kalambo Lodge, Zambia.

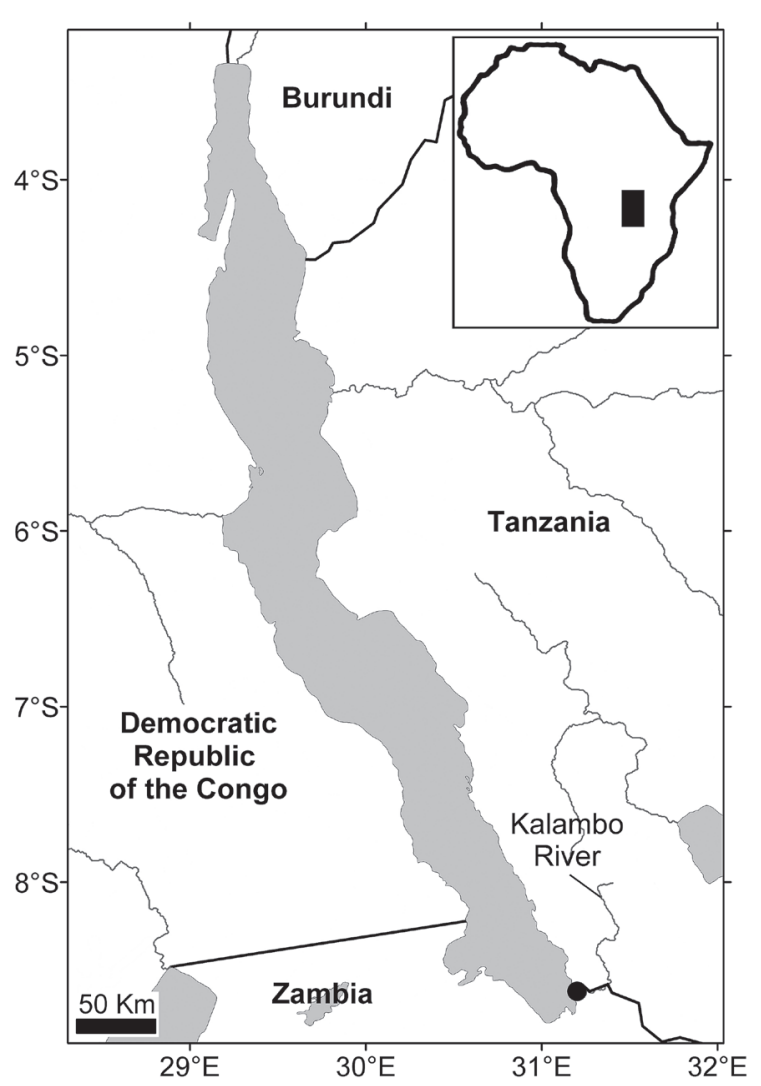

Fig. 2. Map indicating Kalambo Lodge, Zambia (black dot), the type locality of the three newly described Cichlidogyrus species.

\section{Discussion}

The diverse ichthyofauna of Lake Tanganyika, and specifically its cichlid assemblage, provides an ideal model system for investigating the influence of history and ecology on host-range and speciation mechanisms in parasites (e.g. Pariselle et al., 2014). In littoral cichlids, such as the endemic Tropheini, monogeneans of the genus Cichlidogyrus are relatively host-specific, i.e. restricted to a single host species, or a limited number of closely related ones (Vanhove, 2012). However, it is unclear whether their host choice is mainly a result of the ecological or rather the phylogenetic situation of the host species and, hence, whether the affinities of the Cichlidogyrus fauna can always provide information on the cichlids' phylogeny. We address this question by studying the monogenean fauna of Interochromis loocki, a tropheine cichlid phylogenetically nested within Petrochromis but ecologically more similar to 'sedimentdwelling' species classified as, e.g. Limnotilapia, Pseudosimochromis or Simochromis.

Three parasite species were retrieved from I. loocki and are described as Cichlidogyrus buescheri Pariselle and Vanhove, sp. nov., C. schreyenbrichardorum Pariselle and Vanhove, sp. nov. and $C$. vealli Pariselle and Vanhove, sp. nov. (see Appendix). These three new species possess anchors in which the blade point is clearly separated from the 'roots', and in which the ventral 
anchor shaft and guard are poorly incised. Such characteristics have not been observed in Cichlidogyrus species previously reported from tropheines (Gillardin et al., 2012; Van Steenberge, 2014). Conversely, these features are found in numerous undescribed congeners infecting a range of Petrochromis species, related to a greater or lesser extent to I. loocki (Fig. 4). It has been shown previously that haptoral elements are valuable for inferring phylogenetic relationships in the lineages of Cichlidogyrus spp. (Pouyaud et al., 2006; Vignon et al., 2011). Genetic data have also suggested that the Cichlidogyrus fauna of I. loocki and Petrochromis spp. are closely related (Vanhove, 2012). This similarity between the Cichlidogyrus fauna infecting I. loocki and the one found on Petrochromis species reflects the affinity between $I$. loocki and members of the former genus, despite their ecological differences. This can hence not be an artefact of parasite transmission in a shared habitat and indicates an important influence of host phylogeny on host range in the Cichlidogyrus assemblage of the Tropheini. Furthermore, it may provide an extra line of evidence supporting the observations of Yamaoka et al. (1998) that, despite its bicuspid frontal teeth, I. loocki is not a member of Simochromis but more closely affiliated to Petrochromis.

Although I. loocki can be easily distinguished from species of Petrochromis by its outer oral dentition (bicuspid versus tricuspid), the phylogenetic position of $I$. loocki renders Petrochromis a paraphyletic genus (Koblmüller et al., 2010). Whether paraphyletic genera are acceptable is currently under debate (Hörandl, 2006; Ebach et al. 2006; Hörandl and Stuessy, 2010). Nevertheless, it could be argued that there is no need to maintain Interochromis as distinct from Petrochromis. When synonymised, species of Petrochromis would then be defined as tropheine cichlids with a loosely set oral dentition.

Alternatively, Interochromis could be enlarged to include $P$. orthognathus and $P$. fasciolatus. These two species are sister to $I$. loocki in a nuclear phylogeny (Koblmüller et al., 2010). Petrochromis orthognathus and $P$. fasciolatus differ from their congeners by their relatively small number of oral teeth (Yamaoka, 1997) and rapid jaw movement while feeding. These traits are shared with I. loocki (Yamaoka et al., 1998). By including P.orthognathus and P.fasciolatus in Interochromis, not all systematic issues in Petrochromis would be solved as three clades are observed in the genus (Koblmüller et al., 2010). The first contains I. loocki, P. orthognathus and $P$. fasciolatus and the second is made up of the 'large' species: P. polyodon Boulenger, 1898, P. trewavasae trewavasae Poll, 1948, P. macrognathus Yamaoka, 1983, P. trewavasae ephippium Brichard, 1989 and P. horii Takahashi and Koblmüller, 2014 as well as several undescribed species (Konings, 1998; Koblmüller et al., 2010). A third clade, containing only P. famula Matthes and Trewavas, 1960 was resolved as sister to the first, although this position has not been supported (Koblmüller et al., 2010). Morphologically, $P$. famula is intermediate between representatives of both clades, as it has many teeth, just like the 'large' Petrochromis species, but it also displays a fast feeding behaviour similar to representatives of the second clade (Yamaoka, 1997). The intermediate position of $P . f a-$ mula is further illustrated by its similarity in general body shape to representatives of the first clade, whereas it clusters with those of the second clade when comparing pharyngeal jaw morphology (Muschick et al., 2012).

The strong host-specificity of these Cichlidogyrus spp. (Vanhove, 2012) can often render these parasites useful markers of their hosts' phylogenetic position. Indeed, the similarity of the Cichlidogyrus fauna infecting species of Interochromis and Petrochromis also reflects the evolutionary affinity between these host genera. It also shows that the host choice of these Tanganyikan Cichlidogyrus spp. can reflect host phylogeny independent of the host's preferred habitat. We therefore propose the use of distribution patterns of gill parasites of the genus Cichlidogyrus to support the (sub-)generic classification of the Petrochromis-Interochromis complex. A similar approach was followed in the 'sediment dwelling' Tropheini (sensu Koblmüller et al. 2010), where the distribution patterns of Cichlidogyrus species and morphotypes provided an extra line of evidence used to re-define the genera Simochromis and Pseudosimochromis (Van Steenberge, 2014).

\section{Acknowledgements}

This is the fifth publication in a series on the ancyrocephalids of Lake Tanganyika. Christian Sturmbauer (Karl-Franzens University Graz, Austria), Lawrence Makasa, Justina Kasabila Zimba (Department of Fisheries, Zambia), Toby Veall and technical staff (Rift Valley Tropicals, Zambia) and Cyprian Katongo (University of Zambia) are gratefully acknowledged for their help in collecting the material for this study, Daniel R. Brooks (University of Toronto, Canada / Universidade Federal do Paraná, Brazil / University of Nebraska State Museum, USA / Debrecen University, Hungary) and Walter A. Boeger (Universidade Federal do Paraná) for useful suggestions and Tobias Musschoot (RMCA) for providing Fig. 2. At the time of conducting this research, M.V.S. and M.P.M.V. were $\mathrm{PhD}$ fellows, and T.H. a post-doctoral 
fellow, of the Research Foundation - Flanders (FWO-Vlaanderen). Field work was funded by travel grants from the Research Foundation - Flanders and the King Leopold III Fund for Nature Exploration and Conservation to M.P.M.V. Currently, M.P.M.V. is supported by the Czech Science Foundation, Project no. P505/12/G112 (European Centre of Ichthyoparasitology (ECIP) - Centre of excellence). This is publication ISE-M 2014-163. Jean-Lou Justine (Muséum National d'Histoire Naturelle, France) and an anonymous referee are thanked for their input.

\section{References}

Barson M, Přikrylová I, Vanhove MPM, Huyse T. 2010. Parasite hybridization in African Macrogyrodactylus spp. (Monogenea, Platyhelminthes) signals historical host distribution. Parasitology 137: 1585-1595.

Boeger WA, Kritsky DC. 2003. Parasites, fossils and geologic history: historical biogeography of the South American freshwater croakers, Plagioscion spp. (Teleostei, Sciaenidae). Zoologica Scripta 32: 3-11.

Boulenger GA. 1898. Report on the fishes recently obtained by Mr. J. E. S. Moore in Lake Tanganyika. Proceedings of the Zoological Society of London 1898 (part 3): 494-497.

Boulenger GA. 1899. Second contribution to the ichthyology of Lake Tanganyika. On the fishes obtained by the Congo Free State Expedition under Lieut. Lemaire in 1898. Transactions of the Zoological Society of London 15(part 4) (1): 87-96.

Boulenger GA. 1914. Mission Stappers au Tanganyika-Moero. Diagnoses de poissons nouveaux. I. Acanthoptérygiens, Opisthomes, Cyprinodontes. Revue Zoologique Africaine 3 (part 3): 442-447.

Brichard P. 1989. Pierre Brichard's book of cichlids and all the other fishes of Lake Tanganyika. Neptune City: T.F.H. Publications.

Cohen AS, Lezzar KE, Tiercelin JJ, Soregan M. 1997. New paleogeographic and lake-level reconstructions of Lake Tanganyika: implications for tectonics, climatic and biological evolution in a rift lake. Basin Research 9: 107-132.

Danley PD, Kocher TD. 2001. Speciation in rapidly diverging systems: lessons from Lake Malawi. Molecular Ecology 10: 1075-1086.

Ebach MC, Williams DM, Morrone JJ. 2006. Paraphyly is bad taxonomy. Taxon 55: 831-832.

Eschmeyer WN (ed). 2014. Catalog of Fishes: genera, species, references (http://research.calacademy.org/research/ichthyology/catalog/fishcatmain.asp). Electronic version accessed 1 August 2014.

Euzet L, Prost M. 1981. Report of the meeting on Monogenea: problems of systematics, biology and ecology. Pp. 1003-1004 in: Slusarski W, ed., Review of advances in parasitology. Warsaw: P.W.N. Polish Scientific Publishers.

Frey JK, Yates TL, Duszynski DW, Gannon WL, Gardner SL. 1992. Designation and curatorial management of type host specimens (symbiotypes) for new parasite species. Journal of Parasitology 78: 930-932.

Gillardin C, Vanhove MPM, Pariselle A, Huyse T, Volckaert FAM. 2012. Ancyrocephalidae (Monogenea) of Lake Tanganyika: II: description of the first Cichlidogyrus spp. parasites from Tropheini fish hosts (Teleostei, Cichlidae). Parasitology Research 110: 305-313.
Greenwood PH. 1978. A review of the pharyngeal apophysis and its significance in the classification of African cichlid fishes. Bulletin of the British Museum of Natural History (Zoology) 33: 297-323.

Greenwood PH. 1979. Towards a phyletic classification of the 'genus' Haplochromis (Pisces, Cichlidae) and related taxa. Part I. Zoological Series 35: 265-322.

Grégoir AF, Hablützel PI, Vanhove MPM, Pariselle A, Bamps J, Volckaert FAM, Raeymaekers JAM. 2014. A link between host dispersal and parasite diversity in two sympatric cichlid fishes of Lake Tanganyika. Freshwater Biology doi: 10.1111/ fwb. 12492 .

Guégan JF, Lambert A. 1990. Twelve new species of dactylogyrids (Platyhelminthes, Monogenea) from West African barbels (Teleostei, Cyprinidae), with some biogeographical implications. Systematic Parasitology 17: 153-181.

Günther A. 1894. Descriptions of the reptiles and fishes collected by Mr. E. Coode-Hore on Lake Tanganyika. Proceedings of the Zoological Society of London 1893 (part 4): 628-632.

Gussev AV. 1962 [1964]. Order Dactylogyridea. Pp. 204-342 in: Bychovskaya-Pavlovskaya IE, Gussev AV, Dubinina MN, Izymova NA, Smirnova TS, Sokolovskaya IL, Shtein GA, Shul'man SS, Epsthein VM, eds, Key to the parasites of freshwater fish of the USSR. Jerusalem: Israel Program for Scientific Translations. [Russian original: Opredelitel' parazitov presnovohnyh ryb SSSR. Moscow-Leningrad: Izadtel'stovo Akademii Nauk SSSR]

Hörandl E. 2006. Paraphyletic versus monophyletic taxa - evolutionary versus cladistic classification. Taxon 55: 564-570.

Hörandl E, Stuessy TF. 2010. Paraphyletic groups as natural units of biological classification. Taxon 59: 1641-1653.

Humason GL. 1979. Animal Tissue Techniques, fourth edition. San Francisco: Freeman and Company.

Koblmüller S, Sefc KM, Sturmbauer C. 2008. The Lake Tanganyika cichlid species assemblage: recent advances in molecular phylogenetics. Hydrobiologia 615: 5-20.

Koblmüller S, Egger B, Sturmbauer C, Sefc KM. 2010. Rapid radiation, ancient incomplete lineage sorting and ancient hybridization in the endemic Lake Tanganyika cichlid tribe Tropheini. Molecular Phylogenetics and Evolution 55: 318-334.

Konings A. 1998. Tanganyika cichlids in their natural habitat. El Paso: Cichlid Press.

Kritsky DC, Boeger WA. 1989. The phylogenetic status of the Ancyrocephalinae Bychowsky, 1937 (Monogenea: Dactylogyroidea). Journal of Parasitology 75: 207-211.

Malmberg G. 1957. On the occurence of Gyrodactylus on Swedish fishes. Skrifter utgivna av Södra Sveriges Fiskeriförening 1956: 19-76. [in Swedish]

Matthes H. 1959. Un cichlide nouveau du Lac Tanganyika: Petrochromis orthognathus $\mathrm{n}$. sp. Revue de Zoologie et de Botanique Africaines 60: 335-341.

Matthes H, Trewavas E. 1960. Petrochromis famula n. sp., a cichlid fish of Lake Tanganyika. Revue de Zoologie et de Botanique Africaines 61: 349-357.

Muschick M, Indermauer A, Salzburger W. 2012. Convergent evolution within an adaptive radiation of cichlid fishes. Current Biology 22: 1-7.

Muterezi Bukinga F, Vanhove MPM, Van Steenberge M, Pariselle A. 2012. Ancyrocephalidae (Monogenea) of Lake Tanganyika: III: Cichlidogyrus infecting the world's biggest cichlid and the non-endemic tribes Haplochromini, Oreochromini and 
Tylochromini (Teleostei, Cichlidae). Parasitology Research 111: 2049-2061.

Nelissen MHJ. 1977. Pseudosimochromis, a new genus of the family Cichlidae (Pisces) from Lake Tanganyika. Revue Zoologique Africaine 91: 730-731.

Paperna I. 1960. Studies on monogenetic trematodes in Israel. 2 Monogenetic trematodes of cichlids. Bamidgeh 12: 20-33.

Pariselle A. 1996. Diversité, spéciation et évolution des Monogènes branchiaux de Cichlidae en Afrique de l'Ouest. $\mathrm{PhD}$ thesis. Perpignan: Université de Perpignan.

Pariselle A, Euzet L. 1995. Gill parasites of the genus Cichlidogyrus Paperna, 1960 (Monogenea, Ancyrocephalidae) from Tilapia guineensis (Bleeker, 1862), with descriptions of six new species. Systematic Parasitology 30: 187-198.

Pariselle A, Euzet L. 1997. New species of Cichlidogyrus Paperna, 1960 (Monogenea, Ancyrocephalidae) from the gills of Sarotherodon occidentalis (Daget) (Osteichthyes, Cichlidae) in Guinea and Sierra Leone (West Africa). Systematic Parasitology 38: 221-230.

Pariselle A, Euzet L. 2003. Four new species of Cichlidogyrus (Monogenea: Ancyrocephalidae), gill parasites of Tilapia cabrae (Teleostei: Cichlidae), with discussion on relative length of haptoral sclerites. Folia Parasitologica 50: 195-201.

Pariselle A, Euzet L. 2009. Systematic revision of dactylogyridean parasites (Monogenea) from cichlid fishes in Africa, the Levant and Madagascar. Zoosystema 31: 849-898.

Pariselle A, Bilong Bilong C, Euzet L. 2003a. Four new species of Cichlidogyrus Paperna, 1960 (Monogenea, Ancyrocephalidae), all gill parasites from African mouthbreeder tilapias of the genera Sarotherodon and Oreochromis (Pisces, Cichlidae), with a re-description of $C$. thurstonae Ergens, 1981. Systematic Parasitology 56: 201-210.

Pariselle A, Morand S, Deveney M, Pouyaud L. 2003b. Parasite species richness of closely related hosts: historical scenario and "genetic" hypothesis. Pp. 147-166 in: Combes C, Jourdan J, eds., Hommage à Louis Euzet - Taxonomie, écologie et évolution des métazoaires parasites. Taxonomy, ecology and evolution of metazoan parasites. Perpignan: Presses Universitaires de Perpignan.

Pariselle A, Boeger WA, Snoeks J, Bilong Bilong CF, Morand S, Vanhove MPM. 2011. The monogenean parasite fauna of cichlids: a potential tool for host biogeography. International Journal of Evolutionary Biology 2011: 471-480.

Pariselle A, Muterezi Bukinga F, Van Steenberge M, Vanhove MPM. 2014. Ancyrocephalidae (Monogenea) of Lake Tanganyika: IV: Cichlidogyrus parasitizing species of Bathybatini (Teleostei, Cichlidae): reduced host-specificity in the deepwater realm? Hydrobiologia doi: 10.1007/s10750-014-1975-5.

Paugy D, Guégan JF, Agnèse JF. 1990. Three simultaneous and independent approaches to the characterization of a new species of Labeo (Teleostei, Cyprinidae) from West Africa. $C a$ nadian Journal of Zoology 68: 1124-1131.

Plaisance L, Littlewood DTJ, Olson PD, Morand S. 2005. Molecular phylogeny of gill monogeneans (Platyhelminthes, Monogenea, Dactylogyridae) and colonization of Indo-West Pacific butterflyfish hosts (Perciformes, Chaetodontidae). Zoologica Scripta 34: 425-436.

Poll M. 1948. Descriptions de Cichlidae nouveaux recueillis par la mission hydrobiologique belge au Lac Tanganika (19461947). Bulletin du Musée Royal d'Histoire Naturelle de Belgique 24: 1-31.
Poll M. 1949. Deuxième série de Cichlidae nouveaux recueillis par la mission hydrobiologique belge en Lac Tanganika (19461947). Bulletin de l'Institut Royal des Sciences Naturelles de Belgique 25: 1-55.

Poll M. 1986. Classifications des Cichlidae du Lac Tanganyika. Tribus, genres et espèces. Mémoire de la Classe des Sciences. Académie Royale de Belgique. Séries 8 45: 1-163.

Pouyaud L, Desmarais E, Deveney M, Pariselle A. 2006. Phylogenetic relationships among monogenean gill parasites (Dactylogyridea, Ancyrocephalidae) infesting tilapiine hosts (Cichlidae): systematic and evolutionary implications. Molecular Phylogenetics and Evolution 38: 241-249.

Raeymaekers JAM, Hablützel PI, Grégoir AF, Bamps J, Roose AK, Vanhove MPM, Van Steenberge M, Pariselle A, Huyse T, Snoeks J, Volckaert FAM. 2013. Contrasting parasite communities among allopatric colour morphs of the Lake Tanganyika cichlid Tropheus. BMC Evolutionary Biology 13: 41.

Regan CT. 1920. The classification of the fishes of the family Cichlidae. I. The Tanganyika genera. Annals and Magazine of Natural History (Series 9) 5: 33-53.

Salzburger W, Mack T, Verheyen E, Meyer A. 2005. Out of Tanganyika: Genesis, explosive speciation and phylogeny of the haplochromine cichlid fishes. BMC Evolutionary Biology 5: 17.

Šimková A, Plaisance L, Matějusová I, Morand S, Verneau O. 2003. Phylogenetic relationships of the Dactylogyridae Bychowsky, 1933 (Monogenea: Dactylogyridea): the need for the systematic revision of the Ancyrocephalinae Bychowsky, 1937. Systematic Parasitology 54: 1-11.

Šimková A, Matějusová I, Cunningham CO. 2006. A molecular phylogeny of the Dactylogyridae sensu Kritsky and Boeger (1989) (Monogenea) based on the D1-D3 domains of large subunit rDNA. Parasitology 133: 43-54.

Smith A. 1838-1847. Pisces. In: Illustrations of the zoology of South Africa; consisting chiefly of figures and descriptions of the objects of natural history collected during an expedition into the interior of South Africa in 1834-36. V. 4.

Snoeks J. 2000. How well known is the ichthyofauna of the large East African lakes? Advances in Ecological Research 31: 17-38.

Sturmbauer C, Salzburger W, Duftner N, Schelly R, Koblmüller S. 2010. Evolutionary history of the Lake Tanganyika cichlid tribe Lamprologini (Teleostei: Perciformes) derived from mitochondrial and nuclear DNA data. Molecular Phylogenetics and Evolution 57: 266-284.

Takahashi T. 2003. Systematics of Tanganyikan cichlid fishes (Teleostei: Perciformes). Ichthyology Research 50: 367-382.

Takahashi T, Koblmüller S. 2014. A new species of Petrochromis (Perciformes: Cichlidae) from Lake Tanganyika. Ichthyology Research 61: 252-264.

Vanhove MPM. 2012. Species flocks and parasite evolution. Towards a co-phylogenetic analysis of monogenean flatworms of cichlids and gobies. $\mathrm{PhD}$ thesis. Leuven: University of Leuven.

Vanhove MPM, Snoeks J, Volckaert FAM, Huyse T. 2011a. First description of monogenean parasites in Lake Tanganyika: the cichlid Simochromis diagramma (Teleostei, Cichlidae) harbours a high diversity of Gyrodactylus species (Platyhelminthes, Monogenea). Parasitology 138: 364-380. (erratum in 138: 403) 
Vanhove MPM, Volckaert FAM, Pariselle A. 2011b. Ancyrocephalidae (Monogenea) of Lake Tanganyika: I: Four new species of Cichlidogyrus from Ophthalmotilapia ventralis (Teleostei, Cichlidae), the first record of this family in the basin. Zoologia (Curitiba, Impresso) 28: 253-263.

Vanhove MPM, Van Steenberge M, Dessein S, Volckaert FAM, Snoeks J, Huyse T, Pariselle A. 2013. Biogeographical implications of Zambezian Cichlidogyrus species (Platyhelminthes: Monogenea: Ancyrocephalidae) parasitizing Congolian cichlids. Zootaxa 3608: 398-400.

Vanhove MPM, Economou AN, Zogaris S, Giakoumi S, Zanella D, Volckaert FAM, Huyse T. 2014. The Gyrodactylus (Monogenea, Gyrodactylidae) parasite fauna of freshwater sand gobies (Teleostei, Gobioidei) in their centre of endemism, with description of seven new species. Parasitology Research 113: 653-668.

Van Steenberge M. 2014. Species and speciation in Tropheus, Simochromis and Pseudosimochromis - a multidisciplinary approach on a cichlid radiation from Lake Tanganyika. $\mathrm{PhD}$ thesis. Leuven: University of Leuven.
Vignon M, Pariselle A, Vanhove MPM. 2011. Modularity in attachment organs of African Cichlidogyrus (Platyhelminthes, Monogenea, Ancyrocephalidae) reflects phylogeny rather than host specificity or geographic distribution. Biological Journal of the Linnean Society 102: 694-706.

Yamaoka K. 1983. A revision of the cichlid fish genus Petrochromis from Lake Tanganyika, with description of a new species. Japanese Journal of Ichthyology 30: 129-141.

Yamaoka K. 1997. Trophic ecomorphology of Tanganyikan cichlids. Pp. 25-56 in: Kawanabe H,Hori M, Nagoshi M, eds., Fish communities in Lake Tanganyika. Kyoto: Kyoto University Press.

Yamaoka K, Hori M, Kuwamura T. 1998. Interochromis a new genus of the Tanganyikan cichlid Fish. South African Journal of Science 94: 381-386.

Received: 22 August 2014

Revised and accepted: 10 October 2014

Published online: 30 January 2015

Editor: R. Sluys 


\section{Appendix}

Family Ancyrocephalidae Bychowsky, 1937

Genus Cichlidogyrus Paperna, 1960

Cichlidogyrus buescheri Pariselle and Vanhove sp. nov.

(Figs 4, 8a, b, 9c).

Type host. Interochromis loocki (Poll, 1949) (symbiotype: MRAC B3-36-P-1).

Infection site. Gills.

Type locality. Kalambo Lodge, Zambia $\left(08^{\circ} 37^{\prime} \mathrm{S} ; 31^{\circ} 12^{\prime}\right.$

E).

Material studied. 10 individuals.

Type material. Holotype: MRAC 37745; paratypes: MRAC 37744, MNHN HEL418, SAMCTA 61809.

Etymology. The specific epithet is given for Heinz Büscher (Germany/ Switzerland), aquarist and collector of Lake Tanganyika cichlids, in gratitude for his selfless contributions to the community of cichlid researchers.

Authorship. Note that the authors of the new taxon are different from the authors of this paper; Article 50.1 and Recommendation 50A of the International Code of Zoological Nomenclature.

Description. Pharynx ovoid. Striated tegument. Dorsal anchor short, with poorly marked shaft (fenestration sometimes present between shaft and guard); blade arched in distal third. Dorsal transverse bar arched with well-developed auricles. Ventral anchor similar to dorsal anchor in shape and size. Ventral transverse bar simple, V-shaped. Uncinuli I short (relative to uncinuli II, pair retaining their larval length: see Pariselle and Euzet,

Table 1. Comparison of body, haptor and genital measurements (in micrometres, average with range and number of observations $n$ in parentheses) of Cichlidogyrus buescheri sp. nov., C. schreyenbrichardorum sp. nov. and C. vealli sp. nov. When $n>30$, average \pm standard deviation is presented.

\begin{tabular}{|c|c|c|c|}
\hline & C. buescheri sp. nov. & C. schreyenbrichardorum sp. nov. & C. vealli sp. nov. \\
\hline Total body length & $373(307-430, n=7)$ & $401(281-515, n=10)$ & $490(412-659, n=16)$ \\
\hline Body width at mid-body & $146(100-224, n=9)$ & $158(108-211, n=11)$ & $178(128-246, n=16)$ \\
\hline Pharynx maximal width & $47(42-58, n=6)$ & $34(31-43, n=7)$ & $38(32-47, n=11)$ \\
\hline Dorsal anchor total length (a DA) & $28(25-31, n=12)$ & $47(43-51, n=18)$ & $34(30-37, n=27)$ \\
\hline Dorsal anchor blade length (b DA) & $24(23-27, n=12)$ & $34(32-37, n=18)$ & $25(22-27, n=27)$ \\
\hline Dorsal anchor shaft length (c DA) & $2(1-2, n=12)$ & $4(2-10, n=19)$ & $3(2-5, n=27)$ \\
\hline Dorsal anchor guard length (d DA) & $9(5-13, n=12)$ & $15(13-17, n=18)$ & $13(10-15, n=27)$ \\
\hline Dorsal anchor point length (e DA) & $10(9-12, n=12)$ & $11(8-12, n=18)$ & $9(7-10, n=27)$ \\
\hline Length of dorsal bar auricle (h DB) & $17(15-20, n=14)$ & $17(14-21, n=20)$ & $15 \pm 1.8(11-19, n=31)$ \\
\hline Dorsal bar maximum width (w DB) & $6(5-8, n=7)$ & $9(8-11, n=11)$ & $8(7-9, n=16)$ \\
\hline Dorsal bar total length (x DB) & $37(31-47, n=7)$ & $54(46-63, n=11)$ & $39(33-48, n=16)$ \\
\hline Distance between dorsal bar auricles (y DB) & $9(7-13, n=7)$ & $18(15-24, n=11)$ & $15(13-18, n=16)$ \\
\hline Ventral anchor total length (a VA) & $29(28-33, n=10)$ & $37(35-41, n=19)$ & $29 \pm 1.3(28-33, n=32)$ \\
\hline Ventral anchor blade length (b VA) & $27(24-28, n=11)$ & $37(33-40, n=19)$ & $29 \pm 1.1(26-32, n=32)$ \\
\hline Ventral anchor shaft length (c VA) & $2(1-3, n=11)$ & $4(2-5, n=20)$ & $3 \pm 0.7(1-5, n=32)$ \\
\hline Ventral anchor guard length (d VA) & $9(7-11, n=10)$ & $7(5-10, n=19)$ & $8 \pm 1.1(5-10, n=32)$ \\
\hline Ventral anchor point length (e VA) & $11(9-13, n=11)$ & $12(10-13, n=19)$ & $11 \pm 0.8(9-13, n=32)$ \\
\hline Ventral bar maximum width (w VB) & $5(5-6, n=7)$ & $7(6-8, n=11)$ & $6(5-7, n=16)$ \\
\hline Length of one ventral bar branch (x VB) & $33(27-37, n=14)$ & $49(42-55, n=21)$ & $42 \pm 2.5(38-48, n=31)$ \\
\hline Length of first pair of uncinuli (UI) & $12(11-13, n=14)$ & $15(14-16, n=22)$ & $14 \pm 0.7(12-15, n=32)$ \\
\hline Length of second pair of uncinuli (UII) & $12(11-13, n=8)$ & $12(11-13, n=13)$ & $12 \pm 0.6(10-13, n=31)$ \\
\hline Length of third pair of uncinuli (UIII) & $17(14-19, n=12)$ & $17(16-19, n=22)$ & $18(14-20, n=22)$ \\
\hline Length of fourth pair of uncinuli (UIV) & $19(16-21, n=12)$ & $22(20-24, n=21)$ & $22(20-24, n=24)$ \\
\hline Length of fifth pair of uncinuli (UV) & $20(17-23, n=12)$ & $24(21-26, n=22)$ & $25(23-27, n=26)$ \\
\hline Length of sixth pair of uncinuli (UVI) & $18(15-20, n=13)$ & $21(18-23, n=22)$ & $22(20-24, n=25)$ \\
\hline Length of seventh pair of uncinuli (UVII) & $16(14-18, n=11)$ & $18(16-20, n=22)$ & $18(16-19, n=26)$ \\
\hline Accessory piece length (AP) & $38(31-52, n=9)$ & $49(44-54, n=12)$ & $52(41-64, n=16)$ \\
\hline Penis total length $(\mathrm{Pe})$ & $53(49-58, n=9$ & $61(58-65, n=12)$ & $50(45-56, n=16)$ \\
\hline Heel length $(\mathrm{He})$ & $8(6-11, n=10)$ & $5(4-8, n=12)$ & $5(4-6, n=16)$ \\
\hline
\end{tabular}



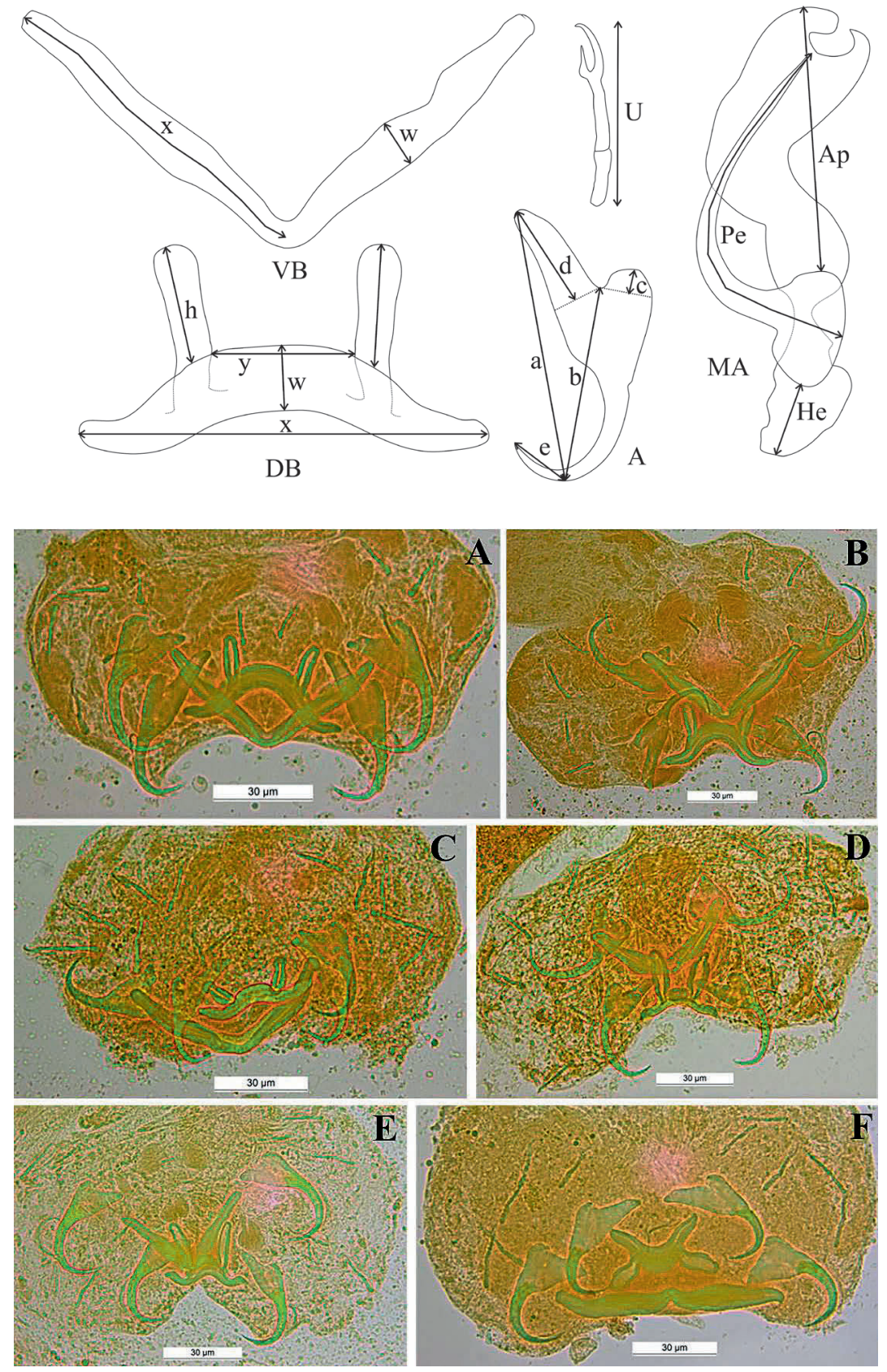

Fig. 3. Measurements used. A, anchor: a, anchor total length; $b$, anchor blade length; $\mathrm{c}$, anchor shaft length; d, anchor guard length; e, anchor point length. DB, dorsal transverse bar: $h$, length of dorsal bar auricle; $w$, dorsal bar maximum width; $x$, dorsal bar total length; $y$, distance between auricles. VB, ventral transverse bar: $w$, ventral bar maximum width; $x$, length of one ventral bar branch. MA, male apparatus: Ap, accessory piece straight length; $\mathrm{Pe}$, penis total curved length; He, heel straight length. $\mathrm{U}$, uncinuli length.

Fig. 4. Haptoral hardparts of Cichlidogyrus infecting Petrochromis. Micrographs $(400 \times)$ of the haptor of parasites, fixed in glycerine ammonium picrate, infecting: A, B, P. fasciolatus (MRAC B0-12-P-861) (phylogenetically close to Interochromis loocki); C, D, P. famula (MRAC B0-12-P-866) (intermediate between the Petrochromis/Interochromis clade and the 'large' Petrochromis clade); E,F, P. trewavasae ephippium (MRAC B0-12-P-867) (a 'large' Petrochromis). Note the kink marking the beginning of the anchor blade points and the little incision between ventral anchor shaft and guard.
2003, 2009); III to VII short (sensu Pariselle and Euzet, 2003, 2009). Penis a curved tube with narrow extremity, beginning in large flattened bulb with large heel of irregular shape. Accessory piece wide, with its distal end pincer-like, directly attached to basal bulb. No sclerotized vagina observed.
Comments. Cichlidogyrus buescheri sp. nov. belongs to the group with short uncinuli I and III to VII (see Vignon et al., 2011). The distinct shape of its accessory piece (with a pincer-like distal end) is reminiscent of C. bifurcatus Paperna, 1960, C. fontanai Pariselle and Euzet, 1997 and C.makasai Vanhove, Volckaert and Pariselle, 

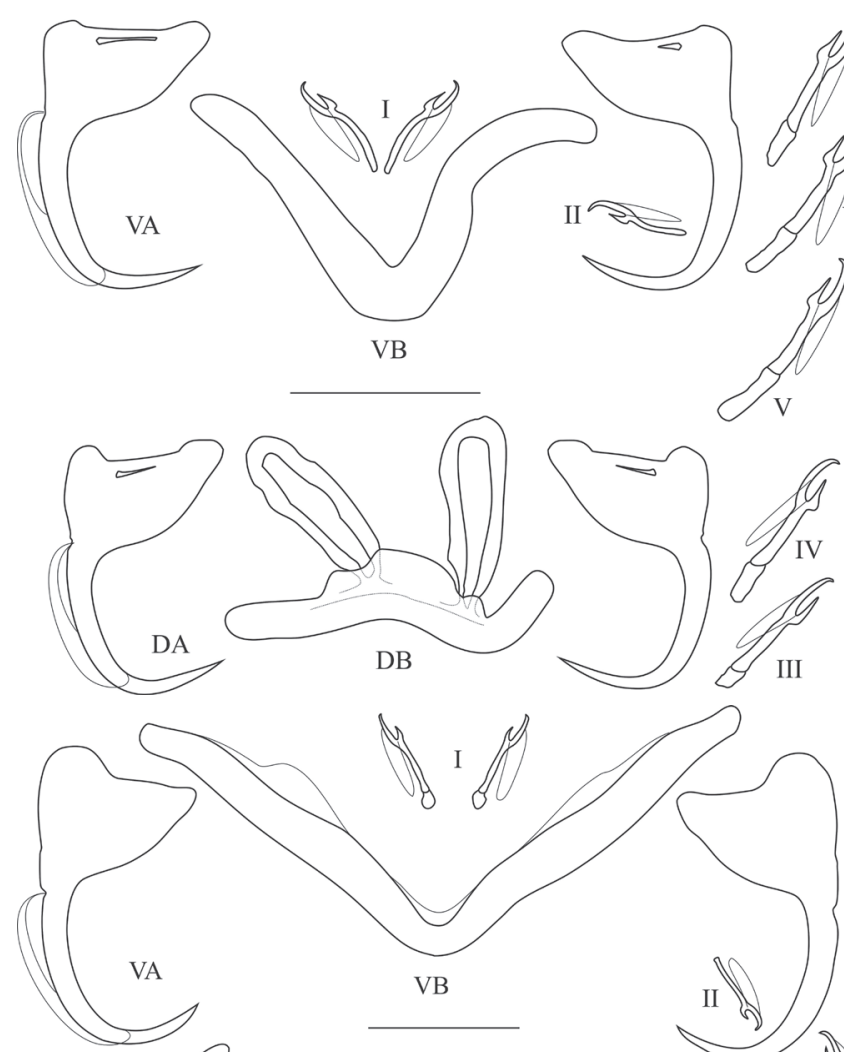

VA
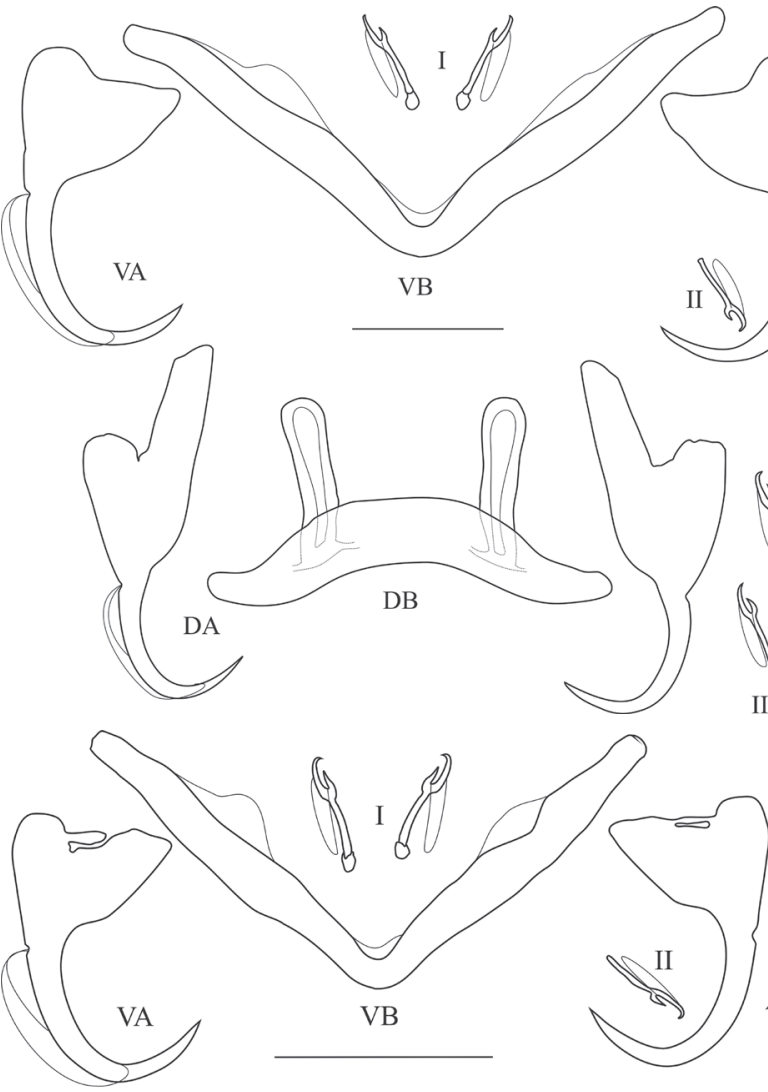

III
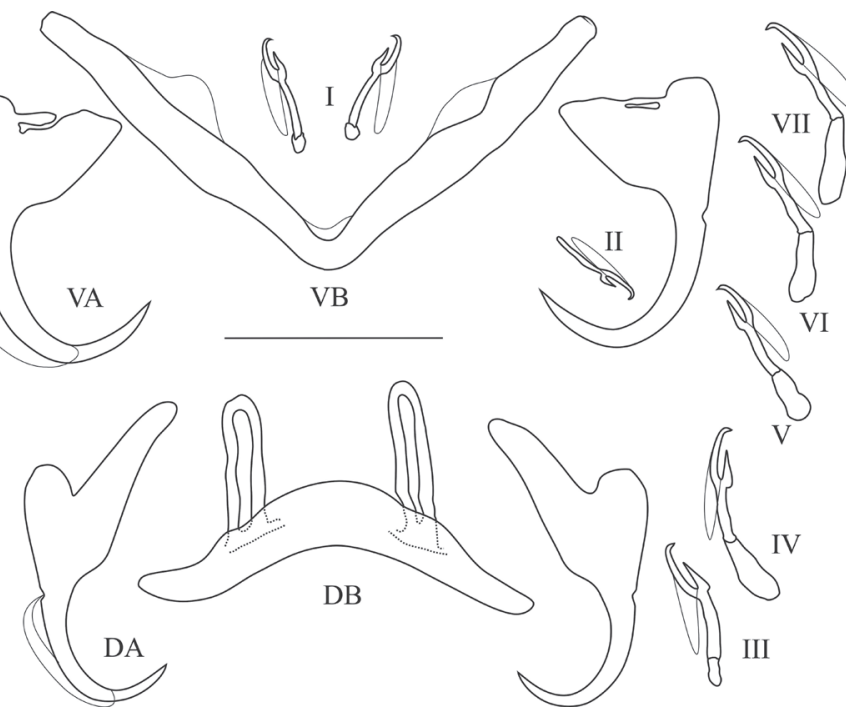

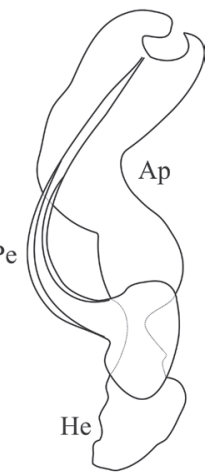

MA

Fig. 5. Haptoral and genital hardparts of Cichlidogyrus buescheri sp. nov. Ap, accessory piece; $\mathrm{DB}$, dorsal transverse bar; DA, dorsal anchor; He, heel; MA, male apparatus; Pe, penis; VB, ventral transverse bar; VA, ventral anchor; I to VII, uncinuli. Scale bar $=20 \mu \mathrm{m}$.

Fig. 6. Haptoral and genital hardparts of Cichlidogyrus schreyenbrichardorum $\mathrm{sp}$. nov. Ap, accessory piece; DB, dorsal transverse bar; DA, dorsal anchor; He, heel; MA, male apparatus; Pe, penis; VB, ventral transverse bar; VA, ventral anchor; I to VII, uncinuli. Scale bar $=20 \mu \mathrm{m}$.

Fig. 7. Haptoral and genital hardparts of Cichlidogyrus vealli sp. nov. Ap, accessory piece; DB, dorsal transverse bar; DA, dorsal anchor; He, heel; MA, male apparatus; $\mathrm{Pe}$, penis; $\mathrm{VB}$, ventral transverse bar; VA, ventral anchor; I to VII, uncinuli. Scale bar $=20 \mu \mathrm{m}$. 

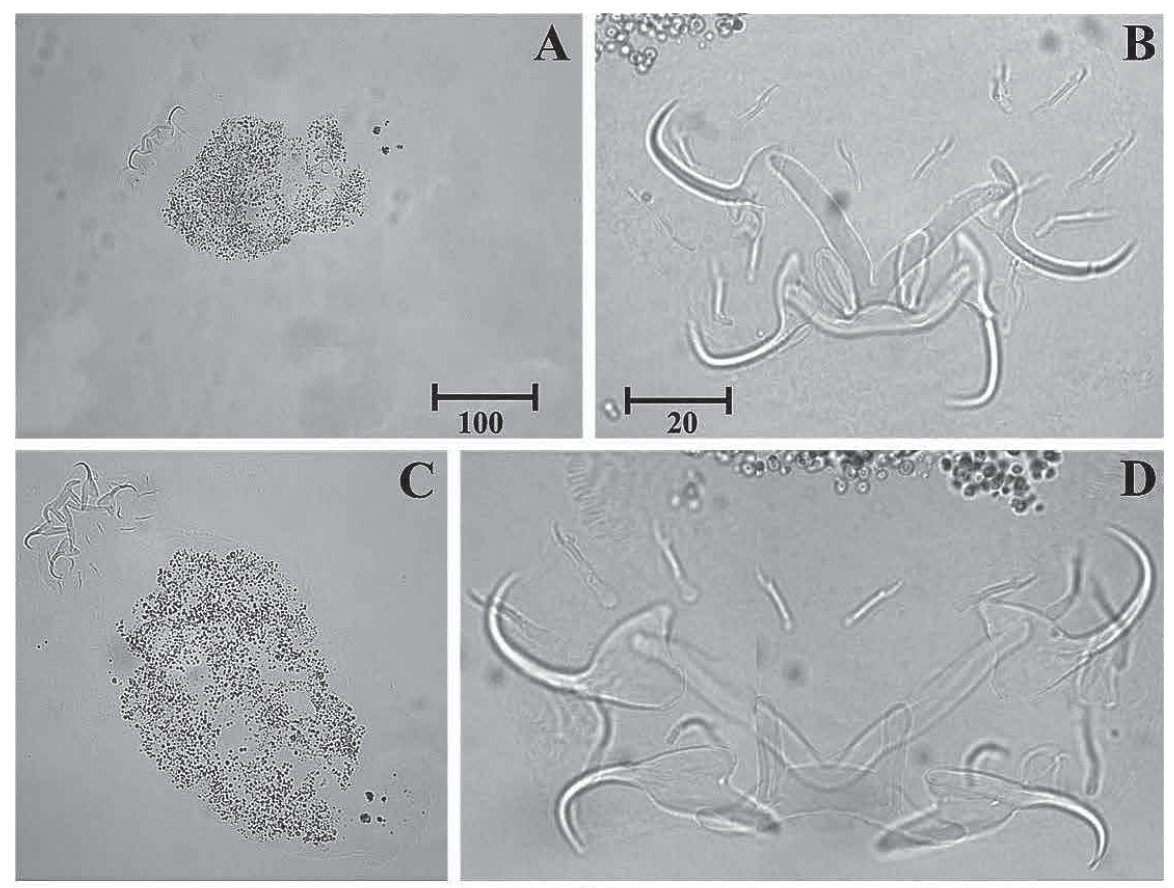

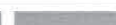

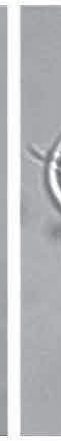

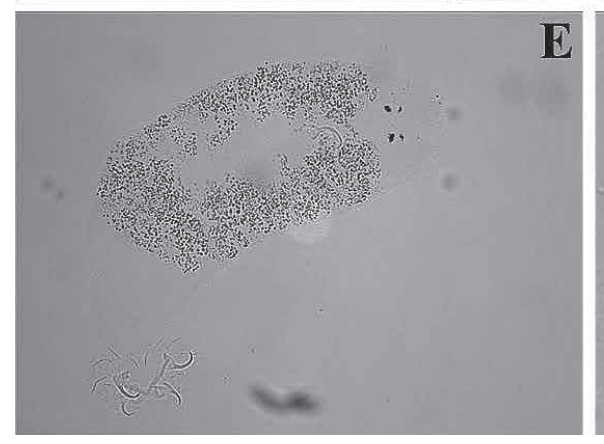

Fig. 8. Whole mount (left) and haptor (right) of the newly described Cichlidogyrus species parasitizing Interochromis loocki. A, B, C. buescheri sp. nov.; C, D, C. schreyenbrichardorum sp. nov.; E, F, C. vealli sp. nov. Micrographs, of specimens fixed in Hoyer's medium, depicted to scale.

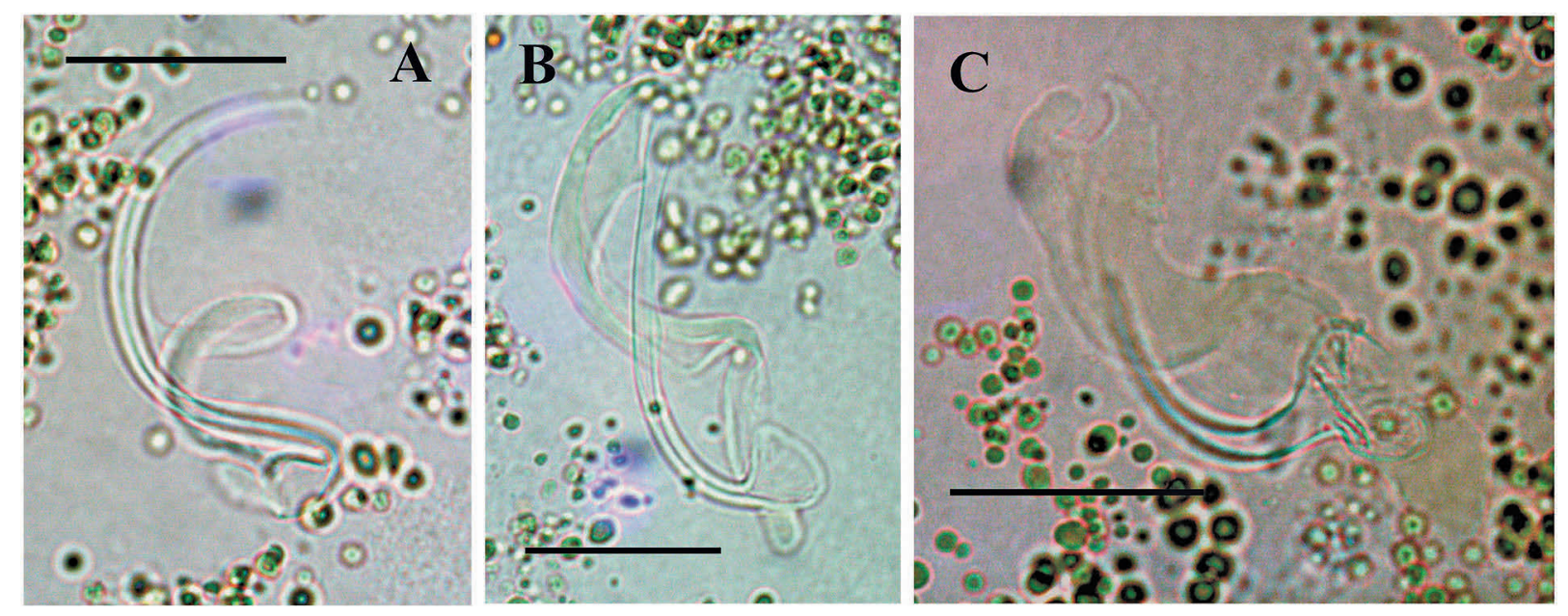

Fig. 9. Comparative morphology of the male apparatus of the newly described Cichlidogyrus species parasitizing Interochromis loocki. Micrographs, of specimens fixed in Hoyer's medium, depict: A, C. schreyenbrichardorum sp. nov.; B, C. vealli sp. nov.; C, C. buescheri sp. nov. Scale bar $=20 \mu \mathrm{m}$. 
2011. It can be distinguished from these species as follows: 1) C. bifurcatus has a straight penis (versus curved in C. buescheri sp. nov.) and an asymmetrical dorsal and ventral anchor with a well-marked shaft and guard (versus similar anchors and poorly marked shaft in $C$. buescheri sp. nov.); 2) $C$. fontanai has a straight penis and a three-pronged accessory piece (versus a curved penis and two-pronged accessory piece in C. buescheri sp. nov.); 3) C. makasai has a longer penis (73 versus 53 $\mu \mathrm{m}$ in C. buescheri sp. nov.) and a short dorsal bar (25 $\mu \mathrm{m}$ versus $37 \mu \mathrm{m}$ in $C$. buescheri sp. nov.), resulting in proportionally long auricles (20 versus $17 \mu \mathrm{m}$ in $C$. buescheri sp. nov.).

Cichlidogyrus schreyenbrichardorum Pariselle and Vanhove sp. nov.

(Figs 5, 8c, d, 9a).

Type host. Interochromis loocki (Poll, 1949) (symbiotype: MRAC B3-36-P-1).

Infection site. Gills.

Type locality. Kalambo Lodge, Lake Tanganyika, Zambia (08 $\left.37^{\prime} \mathrm{S} ; 31^{\circ} 12^{\prime} \mathrm{E}\right)$.

Material studied. 12 individuals.

Type material. Holotype: MRAC 37741; paratypes: MRAC 37740-1, MNHN HEL416, SAMCTA 61811.

Etymology. the specific epithet is given in honour of the Schreyen-Brichard family (Burundi / Belgium) in recognition of their countless contributions to Lake Tanganyika ichthyology, and their hospitality and active assistance towards African and other researchers active in the region.

Authorship. Note that the authors of the new taxon are different from the authors of this paper; Article 50.1 and Recommendation 50A of the International Code of Zoological Nomenclature.

Description. Pharynx ovoid. Tegument striated. Dorsal anchor large, with marked shaft, long guard and arched blade. Dorsal transverse bar large, arched, with narrow auricles; extremities sometimes bent anteriorly. Ventral anchor with poorly marked guard and shaft, shorter but more robust than dorsal anchor, with blade and total length of same size. Ventral transverse bar V-shaped, large, thick. Uncinuli I short; III to VII short (sensu Pariselle and Euzet, 2003, 2009). Penis a thin tube of almost constant diameter, at acute angle with basal bulb; heel relatively small, slender but well developed. Acces- sory piece simple, thin and coiled (one turn), attached to basal bulb ( $\mathrm{J}$-shaped) and curved around penis in middle (rarely straight). No sclerotized vagina observed.

Comments. Cichlidogyrus schreyenbrichardorum sp. nov. also has short uncinuli I and III to VII. It is unique in the shape of its penis ( $\mathrm{J}$-shaped, with a constant diameter) and associated accessory piece (spirally coiled (1 turn), wound around the penis and attached to the basal bulb). Only Cichlidogyrus sp.1 (from Grégoir et al., 2014) and C. reversati Pariselle and Euzet, 2003 resemble C. schreyenbrichardorum sp. nov. However, C. reversati has a large first pair of uncinuli (versus short in C. schreyenbrichardorum sp. nov.) and the distal end of its penis is folded back (versus straight in C. schreyenbrichardorum sp. nov.). Cichlidogyrus sp.1 (from Grégoir et al., 2014) has a short, wide penis with a bevelled extremity, whereas this organ is J-shaped and straight in $C$. schreyenbrichardorum sp. nov.. Moreover, $C$. schreyenbrichardorum sp. nov. is the only known species of Cichlidogyrus with the ventral anchors having a total length and blade length of the same size $(a=b)$.

Cichlidogyrus vealli Pariselle and Vanhove sp. nov. (Figs 6, 8e, f, 9b)

Type host. Interochromis loocki (Poll, 1949) (symbiotype: MRAC B3-36-P-1).

Infection site. Gills.

Type locality. Kalambo Lodge, Lake Tanganyika, Zambia (08³7' S; 31 ${ }^{\circ} 12^{\prime}$ E).

Material studied: 16 individuals.

Type material. Holotype: MRAC 37743; paratypes: MRAC 37742-3, MNHN HEL417, SAMCTA 61810.

Etymology. The specific epithet refers to Toby Veall (Zambia / United Kingdom) in gratitude for his contributions to countless Lake Tanganyika expeditions.

Authorship. Note that the authors of the new taxon are different from the authors of this paper; Article 50.1 and Recommendation 50A of the International Code of Zoological Nomenclature.

Description. Pharynx ovoid. Tegument striated. Dorsal anchor with well-developed and distinct shaft; blade arched in distal third. Dorsal transverse bar arched with narrow auricles. Ventral anchor shorter but more robust than dorsal anchor, with poorly marked guard and shaft (fenestration sometimes present between shaft and 
guard); blade length and total length similar. Ventral transverse bar V-shaped. Uncinuli I short; III to VII short (sensu Pariselle and Euzet, 2003, 2009). Penis a tube of mostly constant length but with enlarged extremity, begins in distinct bulb with short, stubby but well-developed heel. Accessory piece, attached to basal bulb, gutter-like, sharply bent in proximal third, with threepronged distal end. No sclerotized vagina observed.
Comments. Like its congeners infecting Interochromis loocki or other tropheine cichlids, Cichlidogyrus vealli sp. nov. belongs to the Cichlidogyrus morphotype with short uncinuli I and III to VII. It can be distinguished from other members of the group by the shape of its penis (tube of generally constant width but with an enlarged extremity) and of the associated accessory piece (a gutter-like structure). 